\title{
Flavonoids in some Iranian Angiosperms
}

\author{
Mitra Noori \\ Department of Biology, Faculty of Science, Arak University, Arak,
}

Iran

\section{Introduction}

Flavonoids are as one set of the polyphenolic compounds among secondary metabolites in different organs of plants that possess a wide range of biological activities [Parr and Bolwell 2000, Noori 2002, Noori et al 2009]. Their distribution in plants, synthesis and mode of action have been extensively studied [Shirley 1996].

\subsection{Structure, biosynthesis and variety}

All flavonoids contain fifteen carbon atoms in their basic nucleus and these are arranged in a $\mathrm{C}_{6}-\mathrm{C}_{3}-\mathrm{C}_{6}$ configuration, that is, two aromatic rings linked by a three carbon unit which may or may not form a third ring. They are divided into different groups depending on the configuration of the rings and substitutions on these rings of a variety of side-groups which characterize the individual compounds [Stace 1980] (Scheme 1).

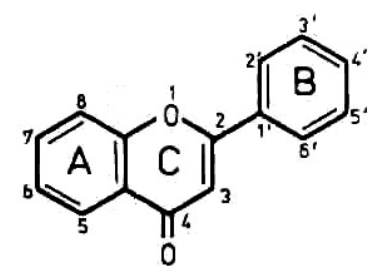

Scheme 1. The basic nucleus of flavonoids (Stace 1980)

The flavonoid variants are all related by a common biosynthetic pathway which incorporates precursors from both the "Shikimate" and "Acetate-Malonate" pathways [Hahlbrock and Grisebach 1975; Wong 1976], the first flavonoid produced immediately following confluence of the two pathways (Scheme 2).

The flavonoid initially formed in the biosynthesis is now thought to be the chalcone and all other forms are derived from this by a variety of routes [Hahlbrock 1981] (Scheme 2). More than 4000 varieties of flavonoids have been identified in different higher and lower plant species (De Groot and Rauen 1998). The main flavonoid groups are flavones (e.g. luteolin), flavanone (e.g. naringenin), flavonols (e.g. kaempferol), anthocyanidins (e.g. pelargonidin) and chalcones (e.g. butein) [Harborne et al 1975]. 


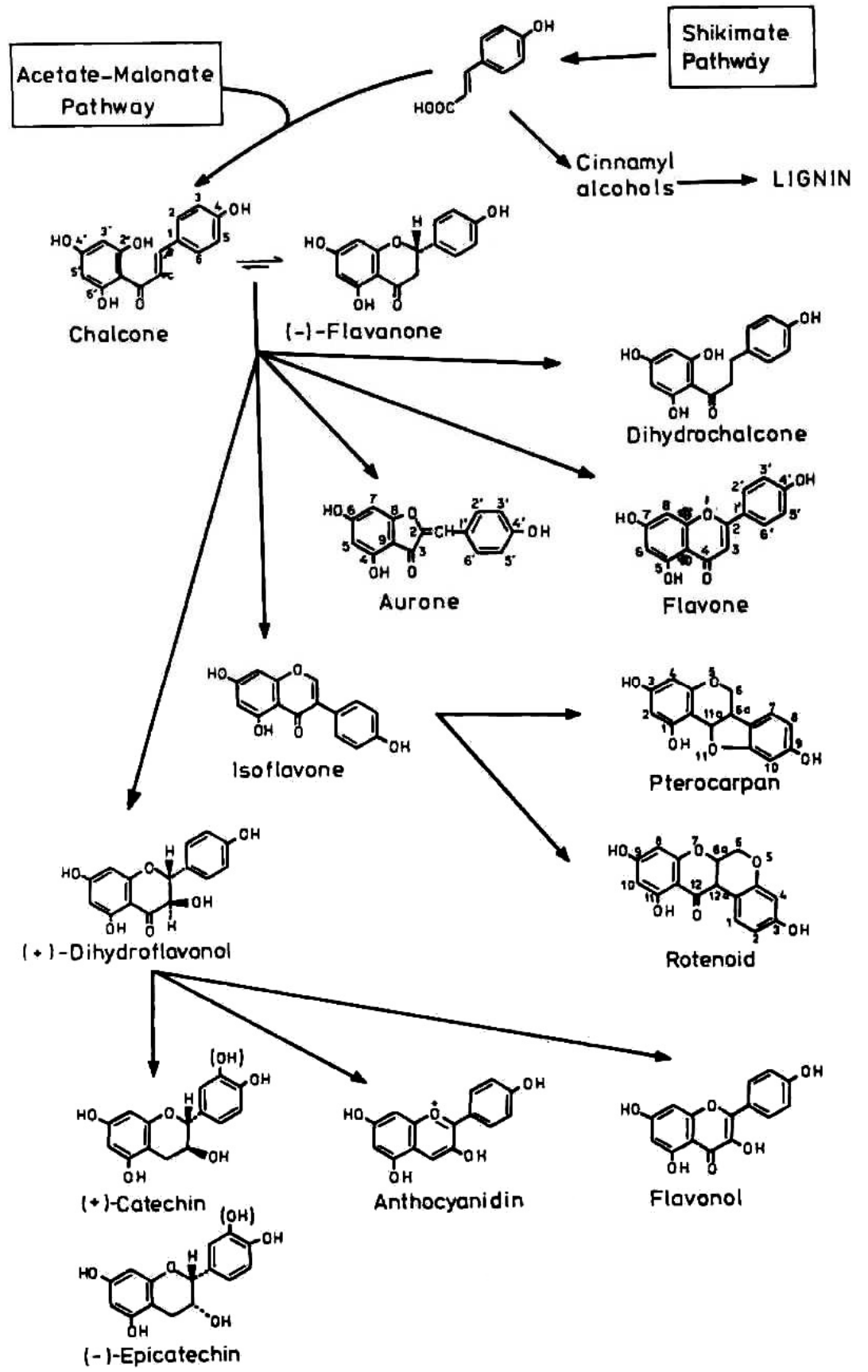

Scheme 2. Showing two biosynthetic pathways of flavonoids (Hahlbrock and Grisebach 1975; Wong 1976). 


\subsection{Occurance}

Flavonoids are found in fruit, vegetables, grains, bark, roots, stems, leaves, flowers, tea and wine [Middleton 1998, Robles et al 2003]. The flavonoid nucleus is normally linked to a sugar moiety to form a water-soluble glycoside. Most flavonoids are stored in the plant cell vacuoles, although they also occur on the surfaces of leaves and stems (Farman 1990). In contrast to earlier studies, all these compounds are no longer judged as waste products, nor as evolutionary remnants without current function, nor as mere metabolic end products that are toxic to the plant and are therefore to be stored away in vacuoles [Parr and Bolwell 2000].

\subsection{Biological activities and their usages}

Flavonoids possess a wide range of biological activities, medicinal and pharmacological effects [Parr and Bolwell 2000, Noori 2002, Noori et al 2009].

\subsubsection{Biological activities}

A large variety of colours such as orange, scarlet, crimson, mauve, violet, blue and purple that we encounter in different part of plants, especially flowers and fruits, are caused by anthocyanins (=anthocyanidin glycosides). Chalcones and some flavones and flavonols also absorb light in the visible region and are associated with bright yellow or cream coloured flowers. Other flavones account for the whiteness in most white flowers, without which they would perhaps appear translucent. Even some of the brown and black pigments found in plants are either due to oxidative products of flavonoids or related phenolic compounds. [Farman 1990]. They are beneficial for the plant itself as physiological active compounds, as stress protecting agents, as attractants or as feeding deterrents, and, in general, by their significant role in plant resistance [Treutter 2006]. Also these compounds serve essential functions in plant reproduction by recruiting pollinators and seed disperses. They are also responsible for the beautiful display of fall color in many plant species, which has recently been suggested to protect leaf cells from photo-oxidative damage, thereby enhancing the efficiency of nutrient retrieval during senescence [Field et al 2001].

\subsubsection{Medicinal and pharmacological effects}

Flavonoids medicinal and pharmacological effects are their contributions to human health which has made them prominent in the past 10 years (Parr and Bolwell 2000). Many flavonoids are active principles of medicinal plants and exhibit pharmacological effects [Yilmaz and Toledo 2004].

\subsection{Chemotaxonomy}

Flavonoid compounds are taxonomically important. They are popular characters for chemosystematic studies because: the almost universal presence of flavonoids in vascular plants; 2. Their structural diversity; 3 . The fact that each species usually contains several flavonoids; 4 . The chemical stability of many flavonoids in dried plant material enabling herbarium material to be used; 5. Flavonoid profiles using different chromatographic techniques are easily obtained. 6 . Flavonoids are reasonably easy to identify using published 
UV spectra data and available standards; 7. Flavonoids often show correlations with existing classifications at the family, genus and species level, and support revisions of existing classifications at the family, genus and species level. However, flavonoids rarely provide "key" characters (the flavonoid may be absent in one or more members of the taxon, and the same flavonoid may occur in an unrelated taxon, e.g. isoflavonoids occur in the Leguminosae and Iridaceae and biflavonyls in the Gymnospermae and some Angiospermae) [Harborne and Turner 1984].

\subsection{Flavonoids in Leguminosae}

The Leguminosae is economically the single most important family in the dicotyledonae, and also of major significance in nature The family is especially rich in flavonoids, producing about $28 \%$ of all known flavonoids and $95 \%$ of all isoflavonoid aglycones (Hegnauer and Grayer-Barkmeijer 1993). The importance of the phenolic constituents in the family has been stressed by Bate-Smith (Bath-Smith 1962). As Gomes et al (1981a) showed in "Advances in Legume Systematics" the Leguminosae are especially well endowed with flavonoid constituents, many of which are only known in these plants. Whithin the Leguminosae, some 850 compounds, including 362 isoflavones, are known [Dewick 1993]. There is a basic structures, Such as genistein (4', 5, 7-trihydroxyisoflavone), 5-dexy derivatives (some $66 \%$ of structures), prenylated derivatives (some $51 \%$ of structures) and compounds with extra hydroxylation (e. g. at the 6-, 8- or 2'-positions). Isoflavonoids usually occur in the free state, and are obtained from root, wood, bark or seed rather than leaf or flower [Ingham 1981, 1983]. Flavonoids, as distinct from isoflavonoids and neoflavonoids, are widespread in the Papilionoidaea and there is little doubt that they occur not only in the species of the some tribes, but will eventually be found in all tribes [Gomes et al 1981b]. Harborn (1965) obtained quercetagetin from hydrolyzed petal of Coronilla glauca $\mathrm{L}$.. He also found halogenin, 3-O rutinoside and limocitrin, 3- $O$ rutinoside from $\mathrm{C}$. glauca flower (Harborn 1981). Catechin, epigallocatechin, leucodelphinidin and 3, 3', 4', 5, 5', 7hexahydroxyflavan have been identified from Alhaji maurorum Medikus ground parts [Islambeko et al 1982]. Malvidin from hydrolyzed flower, myricitrin from flower and laef of Cercis siliquastrum L. have been isolated [Torck et al 1969, Sagareishvili and Ananiya 1990].

\subsection{Polygonaceae flavonoids}

Based on Isobe and Noda (1987) flavonoids and flavonol glycosides are of wide-spread occurrence in the genus Polygonum. Among them, glycosylation at C-3 of the quercetin nucleus has been found to be the most common trend, and present in all species of this genus [Park, 1987]. While rhamnose, gloucose, arabinose and rhamnosyl-rhamnose are the most common sugars found as aglycones of the flavonol glycosides [Mun and Park 1995], galactosylation is rather uncommon in the genus Polygonum or in the family polygonaceae [Collins et al 1975]. Kawasaki et al (1986) isolated thirty-three kinds of flavonoids from Polygonaceae species leaves. Quercetin glycosides were commonly found in the family. In the quercetin glycosides, 3-O-rhamnoside was most frequently found, 3-O-glucuronide is also distributed widely. Myricetin glycosides were rare. Methylated flavonols were found in some species of the section Echinocaulon and Persicaria [Kawasaki et al 1986]. The aerial exudate of Polygonum senegalense has been reported to contain 12 flavonoids of the chalcone 
and flavanone types, and they are distinctly different from internal tissue aglycones [Midiwo et al 2007]. Also Hsu (2006) studies revealed that Polygonum aviculare L. extract has high phenolics and flavonoid contents.

Trichopoulou et al (2000) showed that some wild edible species of Rumex such as R. acetosa L. and R. japonicas Houttuyn have a very high flavonol content. Hasan et al (1995) studies showed besides rutin, quercetin 3-rhamnoside and kaempferol 3-rhamnosyl (1 -> 6) galactoside, a new flavonol glycoside, quercetin 3-glucosyl (1 -> 4) galactoside, and 1, 6, 8trihydroxy-3-methyl anthraquinone (emodin) have been characterized from leaves of $R$. chalepensis.

\subsection{Euphorbiaceae flavonoids}

Several studies indicated that flavonoids occurred in various species of Euphorbia. Nagase reported the isolation of 5, 7, 4'-trihydroxy-flavone-7-glucoside from the leaves and stems of E. thymifolia [Nagase et al 1942]. Ten years later, quercetin was isolated from ethyl acetate extract of aqueous solution of hydroalcoholic extract of E. pilulifera [Hallett and Parks 1951]. Sotnikova and his coworkers identified 3', 4'-pentahydroxyflavone 3 $\beta$-D-galactopyranoside, steppogenin stepposide, isomyricitrin and nineteen other flavonoids in E. stepposa [Sotnikova and Litvinenko 1968, Sotnikova et al. 1968]. Muller and Pohl (1970) isolated six new flavonoids all being glycosides of rhamnetin from E. amygdaloides. The qualitative composition of flavonoids in alcoholic extract of E. helioscopia indicated fifteen substances with flavonoidal nature, by two-dimentional paper chromatography. Acid hydrolysis of $E$. helioscopia alcoholic extract by Volobueva (1970) yielded quercetin and kaempferol. Quercetin-3-xylosidoglucoside has been identified as one of the two flavonoids found in methanolic extract of $E$. chamaesyce and quercetin-3 $\beta$-D-galactopyranoside gallate has been reported in E. verrucosa and E. platiphyllos [Singla and Pathak 1990]. Chromatography on cellulose of methanolic extract of E. lucida yielded quercetin and its derivatives, viz., isoquercetin, avicularoside, hyperoside and rutoside [Burzanska 1975]. The hypotensive principales of E. maddeni were found to be kaempferol-4'-O-glucose and hyperin (Sahai et al 1981). In an effort to identify the constituents responsible for the antiviral activity of $E$. grantii. Van Hoof et al. (1984) isolated derivatives of 3-methylquercetin. Polyphenolic components from the aerial parts of E. soongarica and E. alatavica have been identified as the esters of gallic acid, luteolin-3-rhamnoside and luteoline-3-galactoside [Omurkhamzinova and Erzhanova 1985]. Gautam and Mukhraya (1981) have isolated quercetin-3-O- $\beta-D-$ glucopyranosyl (1-4)-O- $-\mathrm{a}-\mathrm{L}-\mathrm{rhamnopyranoside}$ from the leaves of $E$. dracuncoloides. Kaempferol 3-O-glucoside and quercetin 3-O-glucoside were obtained from E. larica, E. virgata, E. chamaesyce and E. magalanta. Also all these taxa, except E. chamaesyce contained kaempferol 3-rutinoside and rutin. E. larica also yielded 6-methoxyapigenin while E. virgata and E. magalanta yielded kaempferol. There is an unknown acytylated kaempferol derivative in E. chamaesyce (Ulubelen et al 1983). Murillo and Jakupovic (1998) identified myricetin-3rhamnoside and one flavonoid glycosides in E. aucherii which was collected in Iran. Aimova

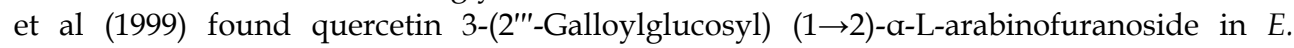
pachyrrhiza. Studies of Halaweish et al (2003) are the first report of quercetin-3-O-O$\beta$ glucuronic acid in E. esula. They separated and identified kaempferol-3-O- $\beta$ glucuronic acid and quercetin-3-O- $\beta$ glucuronic acid from the species. Papp et al (2005) studies showed arial 
parts of Euphorbia cyparissias had 2 main flavonoids: kamfpherol-3-glucuronide and quercetin-3-glucuronide. Adedapo et al (2005) showed arial branch extract of E. hirta contains kaempferol, quercitol and quercitrin. The phytochemical studies of Falodun et al (2006) on E. heterophylla extract revealed the presence of flavonoids in the extract.

Abdel-Sattar (1985) reported existing flavonoids in Chrozophora. Then Hashim et al (1990) found kampferol, acacetin, luteolin and apigenin glycosides in Chrozophora species. Isorhamnetin and quercetin glycosides were separated from C. oblique [Mohamed 2001]. Talischi et al (2005) reported apigenin and quercetin glycosides from metanolic extract of $C$. tinctoria aerial parts. Also Delazar et al (2006) separated 5-flavonoid glycosid from aerial parts metanolic extract of C. tinctoria. Shi et al (2006) has reported 7-flavonoid glycoside from C. sabulosa species. Vassallo et al (2006) were separated three new flavon glycosids from $C$. senegalensis leaf metabolic extract. Apigenin and loteulin glycosids were reported from leaf aqueous-etanolic extract of C. brocchiana species [Hawas 2007].

\subsection{Resedaceae flavonoids}

Several studies indicated that flavonoids occurred in various species of Reseda. Eight flavone, 15 flavonols and one isoflavone have been reported from the Reseda. Reseda luteola contains $40 \%$ flavonoids, primarily luteolin, but also luteolin-7-O glucoside and apigenin [Woelfle et al 2009]. Moiteiro et al (2008) found luteolin 4-O-glucoside in Reseda luteola for first time. Berrahal et al (2006) reported five flavonoid glycosides, quercetin-7-O- $\alpha-L-r h a m n o s y l-3-O-\beta-D-$ glucoside, isorhamnetin-3 O- $\beta$-D-glycosyl-7-O- $\alpha-L-r h a m n o s i d e, \quad k a e m p f e r o l-7-O-\alpha-L-$

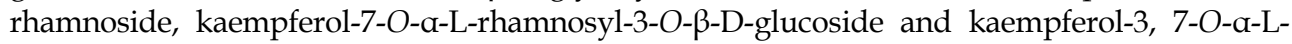
dirhamnoside from aerial parts of $R$. villosa for first time. El-Sayad et al (2001) isolated aglycone flavonols, kaempferol and quercetin from the Mediterranean Reseda species. Also Yuldashev et al (1996) reported flavonol diglycosides of kaempferol, quercetin and isorhamnetin from four other Reseda species. Rzadkowska (1969) isolated four 3-O-glycosides from R. lutea.

\subsection{Cyperaceae flavonoids}

Clifford and Harborne (1969) studies showed identification of the flavonoid pigment aureusidin from Scirpus nodosus. Quercetin, kaempferol, apigenin and luteolin were reported from S. wichurai [Ahmed et al 1984]. Naser et al (2000) identified lupeol betulin, betulinalaldehyde and apigenin from Scirpus tuberosus. Also $\beta$-sitosterol, quercetin 3- $\beta$ glucoside, quercetin 3, 7- $\beta$-diglucoside and isorhamnetin 3, 7- $\beta$-glucoside were identified from Scirpus litoralis using spectroscopic analyses [Naser et al 2000]. Yang et al (2010) used a developed capillary electrophoresis with amperometric detection method for the determination of some phenolic compounds in the rhizome of Scirpus yagara Ohwi. Their work determined existing four phenolic compounds: transresveratrol, scirpusin A, scirpusin $\mathrm{B}$, and p-hydroxycinnamic acid in the species rhizome.

\subsection{Aim}

The aim of this study was to compare the leaf flavonoids profiles of some Iranian Angiosperm species from Leguminosae, Polygonaceae, Euphorbiaceae, Resedaceae and Cyperaceae. 


\section{Materiales and methodes}

\subsection{Collection of plant material and praperation}

Mature fresh leaves of eight Legumes, seven Polygonum, seven Rumex, seventeen Euphorbia, two Chrozophora, four Reseda and five Scirpus species from different parts of Iran were collected during 2006-2010 as described in Table 1. Plants identified using available references [Rechinger 1964, Mobayen 1979, 1980, Ghahreman 1979-2006]. Specimens of each sample were prepared for reference as herbarium vouchers that were deposited the Arak University herbarium. Samples were air dried for detection and identification of flavonoids.

\subsection{Extraction of the plant material}

For a comparative analysis of the flavonoids, small extracts of all the accessions were prepared by boiling $200 \mathrm{mg}$ of powdered air dried leaf material for $2 \mathrm{~min}$ in $5 \mathrm{ml}$ of $70 \%$ EtOH. The mixture was cooled and left to extract for $24 \mathrm{~h}$. The extract was then filtered, evaporated to dryness by rotary evaporation at $40^{\circ}$, and taken up in $2 \mathrm{ml}$ of $80 \% \mathrm{MeOH}$ for analysis by 2-Dimensional Paper Chromatography (2-D PC).

\subsection{Flavonoid analysis by 2-Dimensional Paper Chromatography (2-D PC)}

For the detection of flavonoids, ca $20 \mu \mathrm{l}$ of each of the small extracts was applied to the corner of a quarter sheet of Whatman No 1 chromatography paper as a concentrated spot (10 applications of $2 \mu \mathrm{l})$. The chromatogram for each sample was developed in BAW (n-BuOHHOAc- $\mathrm{H}_{2} \mathrm{O}=4: 1: 5 ; \mathrm{V} / \mathrm{V}$; upper layer), $1^{\text {st }}$ direction, and HOAc ( $=15 \%$ aqueous acetic acid), 2nd direction, with rutin (= quercetin 3-O-rutinoside) as a standard. After development, the chromatograms were viewed in longwave UV light $(366 \mathrm{~nm})$ and any dark absorbing and fluorescent spots were marked. $\mathrm{R}_{\mathrm{f}}$-values in BAW and $15 \%$ HOAc were calculated.

\subsection{Methods of identification of the flavonoids}

When sufficient amounts of purified flavonoids had been obtained, as in the cases of the flavonoids from studied samples, they were identified by means of UV spectroscopy using shift reagents to investigate the substitution patterns of the flavonoids [Mabry et al. 1970, Markham 1982] and by acid hydrolysis to identify the aglycone and sugar moieties. Cochromatography with standards was also performed where possible. Flavonoid standards available for comparison during the study obtained commercially from Merck, Sigma and Fluka.

\subsection{Acid hydrolysis and identification of flavonoid aglycones}

A small amount of each purified flavonoid (ca $0.5 \mathrm{mg}$ ) was dissolved in $0.5 \mathrm{ml}$ of $80 \%$ $\mathrm{MeOH}$ in a test tube. To this sample $2 \mathrm{ml}$ of $2 \mathrm{M} \mathrm{HCl}$ were added and the mixture was heated in a water bath at $100^{\circ} \mathrm{C}$ for $0.5 \mathrm{~h}$. The solution was cooled, $2 \mathrm{ml}$ of EtOAc were added and thoroughly mixed with the aqueous layer using a whirley mixer. The upper EtOAc layer was removed with a pipette, evaporated to dryness, dissolved in $0.5 \mathrm{ml}$ of $\mathrm{MeOH}$ and applied as spots on thin layer chromatograms (cellulose). The TLC plates were run in three solvents alongside standards to identify the aglycone moiety [Harborne 1998]. 


\begin{tabular}{|c|c|c|c|c|c|}
\hline $\begin{array}{l}\text { Voucher } \\
\text { data }\end{array}$ & Taxon & $\begin{array}{c}\text { Number of } \\
\text { total } \\
\text { flavonoids }\end{array}$ & $\begin{array}{c}\text { Number of } \\
\text { flavonoid } \\
\text { sulphates } \\
\end{array}$ & $\begin{array}{c}\text { Number of } \\
\text { flavone C-and } \\
\text { C-/O-glucosides }\end{array}$ & $\begin{array}{l}\text { Number of } \\
\text { aglycones }\end{array}$ \\
\hline & Chrozophora & & & & \\
\hline${ }^{*}$ CAM2 & C. tinctoria & 3 & 3 & 2 & 8 \\
\hline \multirow[t]{2}{*}{ CAM22 } & C. hierosolymitana & 3 & 2 & 3 & 8 \\
\hline & Euphorbia & & & & \\
\hline *CMK 23 & E. bungei Boiss. & 5 & 2 & 3 & 0 \\
\hline CMK 65 & E. chamaesyce $\mathrm{L}$. & 8 & 4 & 4 & 0 \\
\hline CMK 57 & E. cheiradenia Boiss. et Hohen. & 7 & 5 & 2 & 0 \\
\hline CMK 63 & E. cordifolia Ell. & 9 & 3 & 6 & 0 \\
\hline CMK 60 & E. esula L. & 7 & 3 & 4 & 0 \\
\hline CMK 59 & E. falcata $\mathrm{L}$. & 7 & 3 & 4 & 0 \\
\hline CMK 32 & E. helioscopia L. & 5 & 3 & 2 & 0 \\
\hline CMK 26 & E. heteradena Jaub,et Spach. & 9 & 3 & 6 & 0 \\
\hline CMK 54 & E. macroclada Boiss. & 6 & 1 & 5 & 0 \\
\hline CMK 70 & E. microsciadeae Boiss. & 9 & 5 & 4 & 0 \\
\hline CMK 69 & E. ozyridiforma Parsa. & 7 & 4 & 3 & 0 \\
\hline CMK 62 & E. peplus L. & 8 & 4 & 4 & 0 \\
\hline CMK 74 & E. petiolata Banks et Soland & 9 & 6 & 3 & 0 \\
\hline CMK 16 & E. seguieriana Necker. & 8 & 5 & 3 & 0 \\
\hline CMK 10 & E. splendida Mobayen. & 7 & 3 & 4 & 0 \\
\hline CMK 48 & E. szovitsii Fisch.\& Mey. & 8 & 5 & 3 & 0 \\
\hline \multirow[t]{2}{*}{ CMK 34} & E. tehranica Boiss. & 8 & 6 & 2 & 0 \\
\hline & Papilionoideae & & & & \\
\hline${ }^{*} \mathrm{CMJ148}$ & Alhagi camelorum Fisch. & 2 & 1 & 1 & 0 \\
\hline CMJ149 & Cercis siliquastrum L. & 2 & 1 & 1 & 0 \\
\hline CMF1 & Coronilla varia $\mathrm{L}$. & 5 & 4 & 1 & 0 \\
\hline CMJ150 & Glycyrrhiza glabra L. & 2 & 1 & 1 & 0 \\
\hline CMJ151 & Medicago sativa $\mathrm{L}$. & 0 & 0 & 0 & 0 \\
\hline CMJ152 & Robina peseudo-acacia $L$. & 4 & 3 & 1 & 0 \\
\hline CMJ153 & Sophora alopecuroides ssp. alopecuroides & 0 & 0 & 0 & 0 \\
\hline \multirow[t]{2}{*}{ CMN1 } & Sophora alopecuroides ssp. tomentosa & 0 & 0 & 0 & 0 \\
\hline & Polygonum & & & & \\
\hline *CEM1 & P. aviculare & 4 & 0 & 4 & 0 \\
\hline CEM2 & P. convolvolus & 1 & 0 & 1 & 0 \\
\hline CEM3 & P. hyrcanicum & 4 & 0 & 4 & 0 \\
\hline CEM4 & P. patulum & 3 & 0 & 3 & 0 \\
\hline CEM5 & P. alpestre & 3 & 0 & 3 & 0 \\
\hline CAM6 & P. arenastrum & 4 & 0 & 4 & 0 \\
\hline \multirow[t]{2}{*}{ CAM7 } & P. persicaria & 3 & 1 & 2 & 0 \\
\hline & Reseda & & & & \\
\hline${ }^{*} \mathrm{CMG} 27$ & Reseda aucheri & 8 & 5 & 3 & 0 \\
\hline CMG21 & R. buhseana Mull-Arg. & 10 & 5 & 4 & 1 \\
\hline CMG22 & R. bungei Boiss. & 8 & 7 & 1 & 0 \\
\hline \multirow[t]{2}{*}{ CMG11 } & R. lutea L. & 7 & 6 & 1 & 0 \\
\hline & Rumex & & & & \\
\hline${ }^{*} \mathrm{CMR} 2$ & R. chalpensis & 10 & 4 & 6 & 0 \\
\hline CMR4 & R. crispus & 6 & 2 & 4 & 0 \\
\hline CMR6 & R. obtusifolius & 10 & 4 & 6 & 0 \\
\hline CMR7 & R. tuberosus & 10 & 5 & 5 & 0 \\
\hline CMR9 & R.pulcher & 8 & 2 & 6 & 0 \\
\hline CMR12 & R. acetosella & 8 & 2 & 6 & 0 \\
\hline \multirow[t]{2}{*}{ CMR14 } & R.conglomeratus & 9 & 2 & 6 & 1 \\
\hline & Scirpus & & & & \\
\hline${ }^{*} \mathrm{CNM} 4$ & S. holoschenus L. & 8 & 4 & 1 & 3 \\
\hline CMN23 & S. lacustris L. & 6 & 5 & 0 & 1 \\
\hline CMN8 & S. littoralis Kuntze & 10 & 8 & 1 & 1 \\
\hline CMN6 & S. maritimus L. & 9 & 5 & 3 & 1 \\
\hline CMN18 & S. multicaule & 12 & 5 & 2 & 5 \\
\hline
\end{tabular}

Table 1. The sampling and also two-dimensional paper and thin layer chromatographically data of 48 studied plant samples from Markazi Province, Iran. 


\begin{tabular}{|c|c|c|c|c|c|c|c|c|c|c|}
\hline \multirow{2}{*}{ Voucher data } & \multicolumn{10}{|c|}{ Identification } \\
\hline & Apigenin & Chrycin & Kaempferol & Luteolin & Myricetin & Naringenin & Quercetin & Rhamnetin & Rutin & Vitexin \\
\hline \multicolumn{11}{|c|}{ 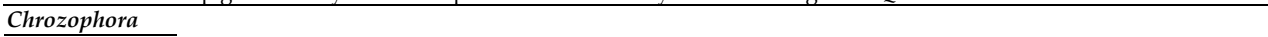 } \\
\hline *CAM2 & ++++ & - & - & - & - & - & +++ & - & ++ & - \\
\hline CAM22 & ++++ & - & - & - & - & - & ++++ & - & - & - \\
\hline Euphorbia & & & & & & & & & & - \\
\hline *CMK 23 & - & - & ++ & - & - & - & +++ & - & ++ & - \\
\hline CMK 65 & - & - & - & - & - & - & +++ & - & +++ & - \\
\hline CMK 57 & - & - & - & - & - & - & +++ & - & +++ & - \\
\hline CMK 63 & - & - & - & - & - & - & - & - & ++ & - \\
\hline CMK 60 & - & - & +++ & - & - & - & +++ & - & + & - \\
\hline CMK 59 & - & - & +++ & - & - & - & ++ & - & +++ & - \\
\hline CMK 32 & - & - & - & - & - & - & +++ & - & + & - \\
\hline CMK 26 & - & - & +++ & - & - & - & ++ & - & ++ & - \\
\hline CMK 54 & - & - & - & - & +++ & - & ++ & - & - & - \\
\hline CMK 70 & - & - & - & - & - & - & +++ & - & +++ & - \\
\hline CMK 69 & - & - & +++ & - & - & - & ++ & - & + & - \\
\hline CMK 62 & - & - & ++ & - & - & - & + & - & ++ & - \\
\hline CMK 74 & - & - & - & - & +++ & - & +++ & - & - & - \\
\hline CMK 16 & - & - & +++ & - & - & - & +++ & - & +++ & - \\
\hline CMK 10 & - & - & - & - & - & - & + & - & + & - \\
\hline CMK 48 & - & - & ++ & - & - & - & +++ & - & ++ & - \\
\hline CMK 34 & - & - & - & - & - & - & - & & + & - \\
\hline \multicolumn{11}{|l|}{ Papilionoideae } \\
\hline${ }^{*}$ CMJ148 & - & - & ++ & - & - & - & -- & - & ++ & - \\
\hline CMJ149 & - & - & ++ & & +++ & & +++ & & ++ & - \\
\hline CMF1 & - & - & - & - & \pm & - & + & + & \pm & - \\
\hline CMJ150 & - & - & -- & - & - & - & ++ & - & ++ & - \\
\hline CMJ151 & - & - & - & - & - & - & - & - & - & - \\
\hline CMJ152 & ++ & & ++ & & - & - & - & - & ++- & - \\
\hline CMJ153 & \pm & - & - & - & - & - & - & - & - & - \\
\hline CMN1 & \pm & - & - & - & - & - & - & - & - & - \\
\hline \multicolumn{11}{|l|}{ Polygonum } \\
\hline${ }^{*}$ CEM1 & - & - & + & - & + & - & + & - & + & - \\
\hline CEM2 & - & - & - & - & - & - & + & - & - & - \\
\hline CEM3 & - & - & + & - & + & - & + & - & - & - \\
\hline CEM4 & - & - & + & - & - & - & + & - & - & - \\
\hline CEM5 & - & - & + & - & - & - & + & - & + & - \\
\hline CAM6 & - & - & + & - & + & - & + & - & + & - \\
\hline CAM7 & - & - & - & - & + & - & + & - & - & - \\
\hline \multicolumn{11}{|l|}{ Reseda } \\
\hline${ }^{*} \mathrm{CMG} 27$ & - & - & + & - & + & - & +++ & ++ & ++ & - \\
\hline CMG21 & - & - & +++ & + & ++ & - & - & - & - & - \\
\hline CMG22 & - & - & +++ & + & ++ & - & - & - & - & - \\
\hline CMG11 & - & - & +++ & ++ & - & - & +++ & \pm & ++ & \\
\hline Rumex & & & & & & & & & + & \\
\hline${ }^{*}$ CMR2 & + & - & + & + & - & - & + & + & & \\
\hline CMR4 & - & - & - & \pm & - & ++ & ++ & + & - & - \\
\hline CMR6 & - & - & \pm & ++ & - & \pm & \pm & + & + & - \\
\hline CMR7 & ++ & - & \pm & - & - & \pm & \pm & ++ & - & - \\
\hline CMR9 & + & - & + & + & - & - & ++ & + & + & - \\
\hline CMR12 & - & - & + & - & - & \pm & +++ & - & - & - \\
\hline CMR14 & + & - & - & \pm & \pm & \pm & ++ & + & - & - \\
\hline \multicolumn{11}{|l|}{ Scirpus } \\
\hline${ }^{*} \mathrm{CNM} 4$ & ++ & + & - & + & - & +++ & + & + & + & + \\
\hline CMN23 & - & \pm & - & + & \pm & \pm & +++ & + & ++ & +++ \\
\hline CMN8 & ++ & + & - & + & - & +++ & - & +++ & + & + \\
\hline CMN6 & - & + & - & + & - & ++ & - & ++ & + & + \\
\hline CMN18 & ++ & + & - & ++ & - & +++ & ++ & ++ & + & ++ \\
\hline
\end{tabular}

${ }^{*} \mathrm{C}=$ Collection number -(non flavonoid), \pm (non or a few flavonoid), + (few flavonoid), ++ (middle concentration of flavonoid), +++ (high concentration of flavonoid)

Table 1. Continued 


\section{Results}

All studied plant species exceptional two subspecies Sophora alopecuroides and Medicago sativa contained flavonoid compounds in their leaves. Their flavonoid profiles show a wide variety between the species. Data in Table 1 shows the sampling and also two-dimensional paper and thin layer chromatographical data of 48 studied plant samples from Markazi Province, Iran.

\section{Discussion}

Studies of leaf flavonoids showed some phytochemical characters such as total number of flavonoids, flavonoid group such as aglycone, flavones $C$ - and $C-/ O$ glycoside and flavonoid sulphate and kind of flavonoids such as kaempherol, quercetin, myricetin are valuable for chemotaxonomy and their usage.

Chemical study of two Chrozophora species using two dimentional paper chromatography (2-DPC) and thin layer chromatography (TLC) showed both Chrozophora species contain flavonoid sulphates, flavone $C$ and $C$ - $/ O$-glycosides and aglycon. Also all of studied species have apigenin and quercetin while rutin was just found in C. tinctoria species that is recorded first time for Markazi Province. All of studied species have flavonoid compounds that have variation in their flavonoid type and number (Table 1).

Phytochemical studies of the Euphorbiaceae have been extremely useful in clarifying systematic relationships within the family (Simpson and Levin 1994). Flavonoids occur widely in plants and are a biologically major and chemically diverse group of secondary metabolites that are popular compounds for chemotaxonomic surveys of plant genera and families [Harborne 1994]. There are some studies in this connection. Mues and Zinsmeister (1988) have discussed about variation of occurrence phenolic compounds in mosses and liverworts. Also they showed there is a clear flavonoid distinction between the subclasses Marchantiidae and Jungermanniidae. Another important chemotaxonomic programme has concerned the ferns and fern allies [Harborne 1986]. The phenolic patterns appear to be more useful for studying relationships within relatively narrow taxonomic limits, e. g. at the species and genus level. Turning to the angiosperms, a chemotaxonomic survey of 255 species of the family Iridaceae has been carried out by Williams et al (1986), who found that flavone C-glycosides were present in $66 \%$ of the samples [Harborne 1986]. Another family survey has been carried out in the Polygonaceae, in which 28 species were analysed for their flavonoid pattern [Harborne 1986]. Studying flavonoid pattern can be used for chemosystematic and lower taxonomic levels. 25 Avena species (Poaceae) were investigated for the flavonoid content of leaf tissue [Saleh et al 1988]. Diploid triticum species could be divided into two groups depending on the presence or absence of two major di-Cglycosylflavones (Harborne et al 1986). Flavonoid data of the genus Vitis indicate three chemical groups [Moore and Giannasi 1994]. Several studies indicated that flavonoids occurred in various species of Euphorbia. They may be useful taxonomic markers within the genus. Also Euphorbia flavonoids are very important for their toxicity and some different potential clinical applications such as their antiatherosclerotic, antiinflammatory, antitumor, antithrombogenic, antiosteoporotic and antiviral effects [Nijveldt et al 2001]. Papp et al (2005) showed populations of Euphorbia cyparissias can be separated clearly from each other according to their morphology and flavonoid pattern.Our results showed all studied 
Euphorbia species contained flavonoid compounds in their leaves that their flavonoid profiles show a wide variety between the taxa. There are flavonoid sulphate and flavone $C$ and $C$-/O-glycosides in all species, but E. bungei, E. heteradena and E. microsciadea in addition these two flavonoid types have dihydroflavonol 3-O-monoglycosides. E. cordifoila, E. heteradena, E. microsciadeae and E. petiolata have the highest number of total flavonoid compounds (9) and E. bungei and E. helioscopia have the lowest number of flavonoid compounds (2) in their leaves (Table 1). Identification of flavonoids by standards showed all of studied Euphorbia species contain rutin with the exception of E. macroclada and E. petiolata. Also all taxa studied, except 2 species (E. cordifolia and E. tehranica) have quercetin. Harborne and Baxter (1999) reported that quercetin is widely distributed in various plant families. Kaempferol found in 8 species and myricetin was found just in E. macroclada and E. petiolata (Table 1). As Volobueva (1970) showed two-dimentional paper chromatography and acid hydrolysis of E. helioscopia alcoholic extract yielded quercetin and kaempferol. Also Gautam and Mukhraya (1981) isolated quercetin 3-O glucoside and kaempferol 3-O glucoside from E. larica, E. virgata, E. chamaesyce and E. magalanta and rutin obtained with the exception $E$. chamaesyce. Both quercetin and kaempferol are flavonols. The flavonols may be among the most important flavonoids, they are the most ancient and widespread of the flavonoids, synthesized even in mosses and ferns, and have a wide range of potent physiological activities [Stafford 1991]. Chemical study of 17 Euphorbia species using two dimentional paper chromatography (2-DPC) and thin layer chromatography (TLC) showed rutin, quercetin and kaempferol are the most representative compounds for the genus and the presence of myricetin is a taxonomic character for separation of some Euphorbia species. It is believed that Euphorbia species can be separated from each other according to their flavonoid pattern.

Application of plant flavonoides data can revealed similarity and relationship between plants and inferring phylogeny and used in their taxonomy. 2-dimentional paper chromatography (2-D PC), on leaves of Alhagi camelorum Fisch, Cersis silliquastrum L., Coronilla varia L., Glycirhiza glarba L. and Robnia peseudoacia from Markazi Province showed all of five named species contain aglycones. A. camelorum and G. glarba had the most flavonoid variation and concentration having flavon glycoside and two subspecies of Sophora alopecuroides and Medicago sativa had not or had the least. The most flavonoid compounds similarity was between C. silliquastrum and R. peseudoacia (Table 1).

Phytochemical examination of the studied polygonum species showed all of Polygonum species contain flavon $C$ - and $C$-/O-glycosides. $P$. hyrcanicum had the most flavonoid variation and concentration and $P$. convolvolus species with having just one flavonoid had the least. Flavonoid sulphates was found just in P. persicaria species (Table 1).

Chemical study of four Reseda species using two dimentional paper chromatography (2-DPC) and thin layer chromatography (TLC) showed all studied Reseda species contained flavonoid compounds in their leaves and kempferol is the most representative compound for the genus (Table 1). They may be useful taxonomic markers within the genus. Also Reseda flavonoids are very important for their toxicity and some different potential clinical applications such as their antiatherosclerotic, antiinflammatory, antitumor, antithrombogenic, antiosteoporotic and antiviral effects [Nijveldt et al 2001]. The presence of quercetin and absence of myrestin in $R$. lutea are taxonomic characters for separation of the species from two other species (R. buhseana and $R$. bungei). Among the many functions of flavonoids at the interface between plant and 
environment, their activity as signals was intensively studied. Flavonoids are also beneficial for the plant itself as physiological active compounds, as stress protecting agents, as attractants or as feeding deterrents, and, in general, by their significant role in plant resistance [Treutter 2006].

Chemical studies of seven Rumex species using two dimentional paper chromatography (2DPC) and thin layer chromatography (TLC) showed all of studied Rumex species contain flavonoid compounds with wide variation. $R$. chalpensis, $R$. obtosifolius and $R$. tuberusos species had the most flavonoid number and $R$. crispus species had the least. Identified flavonoid compounds in all of studied species with the exception $R$. crispus (lack flavonoid sulphate) are flavones $C$ and $C-/ O$ glucoside. $R$. acetosella and $R$. conglomerates had aglycon. Rutin and luteolin found in all of studied species exceptional R. chalpensis, R. obtosifolius and R. pulcher. All of studied species showed wide variation in existing and concentration of myricetin, apigenin, narengenin, rhamnetin, quercetin and kaempferol. All of studied species with the exception $R$. chalpensis and $R$. tuberusos had quercetin and also kaempferol found in 3 species (R. chalpensis, R. pulcher and R. acetosella) (Table 1).

Phytochemical studies on five species of Scirpus (S. holoschenus L., S. lacustris L., S. littoralis Kuntze, S. maritimus L. and S. multicaule) from different parts of Markazi Province, Iran area using two-dimentional paper chromatography (2-DPC) and thin layer chromatography (TLC) showed all of studied taxa contain vitexin, luteolin, rutin and rhamnetin. There were chrysin and naringenin in all of populations with the exception of S. lucustris and apigenin was found in 3 species weheras others lack. Quercetin was not found in S. maritimus and $S$. littoralis where as three other species had (Table 1).

Our studies showed the most of collected plant species are weed and grow in poor soils and destroyed pasture. Progress continues to be made in understanding the roles of flavonoids in stress protection, as well as in defining the mechanisms that control the amount and varieties of flavonoids that are produced in plants in responses to diverse environmental cuse [Chalker-Scott 1999]. Finally, further work is needed using high performance liquid chromatography with diode array detection, atmospheric pressure chemical ionization liquid chromatography-mass spectroscopy to evaluate all flavonoid profiles in studied and other species.

\section{References}

Abdel-Sattar EA. (1985). A Pharmacognostical Study of Chrozophora plicata (Vahl.) Growing in Egypt. MSc thesis. Faculty of Pharmacy. Cairo University. Cairo Egypt.

Adedapo, A. A., Abatan, M. O., Idowu, S. O. \& Olorunsogo, O. O. (2005). Effects of chromatographic fractions of E. hirta on the rat serum biochemistry, African Journal of Biomedical Research, 8: 185-189.

Ahmed, J., Shamsuddin, K. M. \& Zamman, A. (1984). J. Indian Chem. Soc., 61, 92.

Aimova, M. Zh., Rakhmadieva, S. B., Erzhanova, M. S. \& Abilov. Zh. A. (1999). Akad. Nauk. Resp. Kaz. Ser. Khim, 26 (see Williams, A. and Grayer, J. R. 2004, Anthocyanins and other flavonoids, Nat. Prod. Rep., 21: 539-573.

Bath-Smith, E. C. (1962) J. Linn. Soc. (Bot.), 58, 95.

Berrahal, D., Kabouche, A., Kabouche, Z \& Bruneau, C. (2006). Flavonoid glycosides from Reseda villosa (Resedaceae), Biochemical Systematics and Ecology, 34: 777-779. 
Burzanska, Z. (1975). Quercetin derivatives of Euphorbia indica W. K., Acta Pol. Pharm., 32 (6): 703-708; Chem. Abstr., 85, 189224v (1976).

Chalker-Scott, L. 1990. Environmental significance of anthocyanins in plant stress responses, Photochem. Photobiol., 70: 1-9.

Clifford, H. T. \& Harborne , J. B. (1969). Phytochemistry, 8, 123.

Collins, F. W., Bohm, B. A. \& Wilkine, C. K. (1975). Phytochemistry, 14, 1099.

De Groot, H. \& Rauen, U. (1998): Tissue injury by reactive oxygen species and the protective effects of flavonoids. Fundam. Clin. Pharmacol., 12, 249-255.

Delazar A 'Talischi B 'Nazemiyeh H 'Rezazadeh H 'Nahar L. \& Sarker SD. (2006). Chrozophorin: a new acylated flavone glucoside from Chrozophora tinctoria (Euphorbiaceae). Revista Brasileira de Farmacognosia. Brazilian J of Pharmacog, 16 (3): 286- 290.

Dewick, P. M. (1993). In J. B. Harborne (ed.) The Flavonoids: Advances in Research since 1986, pp. 117-238. Chapman \& Hall, London.

El-Sayad, N. H., Omara, N. M., Yosef, A. K., Farag, A. M. \& Mabry, T. J. 2001. Kaempferol triosides from Reseda muricata, Phytochemistry, 57 (4): 575-578.

Falodun, A., Okunrobo, L. O. \& Uzoamaka, N. (2006). Phytochemical screening and antiinflammatory evaluation of methanolic and aqueous extracts of Euphorbia heterophylla L. (Euphorbiaceae), African Journal of Biotechnology, 5 (6): 529-531.

Farman, M. (1990). Isolation and characterization of flavonoids from Indigofera hebepetala, Quaid-i- A Azam University, Islamabad.

Field, T. S., Lee, D. W. \& Holbrook, N. M. (2001). Why leaves turn red in autumn, The role of anthocyanins in senescing leaves of Red-Osier Dogwood, Plant Physiol., 127: 566-574.

Gautam, R. K. and Mukhraya, D. K. 1981. Natl. Acad. Sci. Lett., 10, 95 (see Singla and Pathak 1990).

Ghahreman, A. 1979-2006. Flore de l'Iran, A join project by the Research Institute of Forests and rangelands (Iran) and Tehran University, Published by RIFR, Ministry of Reconstruction Jahad, Volumes 1-24.

Gomes, C. M. R., Gottlieb, O. R., Bettolo, G. B. M., Monache, F. D. \& Polhill, R. M. (1981b). Systematic significance of flavonoids in Derris and Lonchocarpus, Biochemical Systematics and Ecology, 9 (2-3): 129-147.

Gomes, C. M. R., Gottlieb, O. R., Gottlieb, R. G. \& Solatino, A. (1981a) Advances in Legume Systematics, 2, 465.

Hahlbrock H. \& Grisebach H (1975) Biosynthesis of flavonoids. In JB Harborne, TJ Mabry, H Mabry, eds, The Flavonoids. Academic Press, San Diego, pp 866-915.

Hahlbrock,K. (1981) in Stumpf,P.K. and Conn,E.E. (eds.), The Biochemistry of Plants, Vol. 7, Academic Press, NY, pp. 425456.

Halaweish, F. Kronberg, S. \& Rice, J. A. (2003). Rodnet and ruminant ingestive response to flavonoids in Euphorbia esula, Journal of Chemical Ecology, 29 (5): 1073-1082.

Hallett, F. P. \& Parks, L. M. (1951). A note on isolation of quercetin from E. pilulifera, J. Am Pharm Assoc., 40: 56-57.

Harborne, J. B (1981). Phytochemistry, 20, 1117.

Harborne J. B. (1965) Plant polyphenols-XIV: Characterization of flavonoid glycosides by acidic and enzymic hydrolyses. Phytochem., 4: 107-120.

Harborne, J. B. (1986). The Flavonoids. Advances in Research, Chapman \& Hall/CRC, Boca Ratón (1986). 
Harborne, J. B. (1994). The Flavonoids: Advance in Research Since 1986, Chapman and Hall, New York (1994).

Harborne, J. B. and Baxter, H. 1999. The handbook of natural flavonoids, Vol. 1, Wiley, Chichester.

Harborne, J. B. \& Turner, B. L. (1984). Plant chemosystematics, Academic Press, London.

Harborne, J. B., (1998). Phytochemistry Methods, $3^{\text {rd }}$ ed. Chapman and Hall, London.

Harborne, J. B., Heywood, V. H. \& Chen, X. Y. (1986). Separation of ostericum from Angelica on the basis of leaf and mericarp flavonoids, Biochem. Syst. Ecol., 14, 81-83.

Harborne, J.B., Mabry, T.J. \& Mabry, H. (Eds.), 1975. The Flavonoids. Chapman \& Hall, London.

Hasan A, Ahmed I, Jay M. \& Voirin B. (1995). Flavonoid glycosides and an anthraquinone from Rumex chalepensis. Phytochemistry 39: 1211-1213.

Hashim OK، Abouzaid MM ‘Abdelgalil FM \& Saleh NAM. (1990). The flavonoids of Egyptian Chrozophora species. Biochem. Syst. Ecol., 18: 151- 152.

Hawas UW. (2007). Antioxidant activity of brocchlin carboxylic acid and its methyl ester from Chrozophora brocchiana. Natural Product Research.; 21 (7): 632- 640.

Hegnauer, R. \& Grayer- and Barkmeijer, R. J. (1993). Phytochemistry, 34, 30.

Hsu, C. Y., (2006). Antioxidant activity of extract from Polygonum, Biological Research, 39 (2): 281-288.

Ingham, J. L. (1981). In R. M. Polhill and P. H. Raven (eds.) Advances in Legume Systematics, pp. 599-626. HMSO, London.

Ingham, J. L. (1983). Fortschritte d. Chem. org. Naturst., 43, 1.

Islambeko, Sh. Yu. Et al. (1982). Khim.Prir. Soedin.: 653; CA 98: 50389c.

Isobe, T., Noda, Y. (1987). Yakugaku Zasshi, 107, 1001.

Kawasaki, M., Kanomata, T. \& Yoshitama, K., 1986. Flavonoids in the leaves of twenty-eight polygonaceous plants. Bot. Mag. (Tokyo) 99, 63\}74.

Mabry, T. J., Markham, K. R. \& Thomas, M. B., 1970. The Systematic Identification of Flavonoids, Springer Verlag, Berlin.

Markham, K. R., 1982. Techniques of Flavonoid Identification, Academic Press, London.

Middleton, E. J., (1998). Effect of plant flavonoids on immune and inflammatory cell function, Adv. Exp. Med. Biol., 439: 175-182.

Midiwo, J. O., F. M. Omoto, A. Yenesew, H. M. Akala, J. Wangui, P. Liyala, C. Wasuna, N. C. Waters (2007). The first 9-hydroxy isoflavanone and anti-plasmodial chalcones from the aerial exudates of Polygonum senegalense. Arkivoc (ix) 21-27.

Mobayen, S. 1979. Iran Vegetation (Vascular Plant Flora), Tehran University Publications, no. 1500/2, Vol. 2: 85-152.

Mobayen, S. 1980. Iran Vegetation (Vascular Plant Flora), Tehran University Publications, no. 1500/2253, Vol. 1: 209-245.

Mohamed KS. (2001). Phenylpropanoid glucosides from Chrozophora oblique. Phytochem.; 58: 615-618.

Moiteiro, C. Gaspar, H., Rodrigues, Al., Lopes, J. F. \& Carnide, V. (2008). HPLC quantification of dye flavonoids in Reseda luteola L. from Portugal, J. Sep. Sci., 31 (21): 3683-3687.

Moore, M. O. \& Giannasi, D. E. (1994). , Plant systematics and evolution, 193 (1-4): 21-36.

Mues, R. \& Zinsmeister, H. D. (1988). The chemotaxonomy of phenolic compounds in Bryophytes. Journal of Hattori Botanical Laboratory, 64: 109-141. 
Muller, R. \& Pohl, R. (1970). Flavonol glycosides of Euphorbia amygdaloides and their quantitative determination, Planta Med., 18 (2), 114-129.

Mun, J. H. \& Park, C. W. (1995). Flavonoid chemistry of Polygonum sect. Tovara (Polygonaceae): A systematic survey, Plant Systematic And Evolution, 196 (3-4): 153159.

Murillo, R. and Jakupovic, J. 1998. Glycosides from Euphorbia aucherii, Ing. Cienc. Quim., 18: 57-60.

Nagase, M. (1942). J. Agr. Chem. Soc. Japan, 17, 183; Chem. Abstr., 36, 3525 (see Singla and Pathak).

Naser, M. I, Abu-Mustafa, E. A., Abdel-Razik \& Dawidar, A. M. (2000). . Lipid and flavonoids from some Cyperaceae plants and their anti-microbial activity, Bul. Nat. Re. Cen. (Cario), 25 (2): 105-113.

Nijveldt, R. J., Van Nood, E., Van Hoof, EC., Boelens, P. G., Van Norren, K. \& Van Leeuwen, P. AM. (2001). Flavonoids: a review of probable mechanisms of action and potential applications, Am. J. Clin. Nutr., 74: 418-425.

Noori, M. (2002). Characterization of the Iranian species of Sophora and Ammodendron (Leguminosae; Sophoreae), PhD Thesis, University of London and Royal Botanic Gardens, Kew, UK.

Noori, M., Chehreghani, A. \& Kaveh, M. (2009). Flavonoids of 17 species of Euphorbia, (Euphorbiaceae) in Iran, Toxicological and Environmental Chemistry, 91 (3): 409-418.

Omurkhamzinova, V. B. \& Erzhanova, M. S., E. E. C. S. (1985). Int. Conf. Chem., Biotechnol. Biol. Act. Nat. Prod. (Proc.), 3rd, Chem. Abstr., 110, 4671g (1989), (see Singla \& Pathak 1990).

Papp, N., Vasas, A., Hohmann, J. \& Szabo, L. G. (2005). Morphological and flavonoid pattern variations within some Euphorbia cyparissias L. populations, Acta Biologica Szegediensis, 49 (1-2): 171-172.

Park, C. (1987), Flavinoid chemistry of Polygonum Sect Echinocaulon: a systematic survey. Syst. Bot, 12: 461-462.

Parr, A. J. \& Bolwell, G. P. (2000). Phenols in the plant and in man. The potential for possible nutritional enhancment of the diet by modifying the phenols content or profile, Journal of the Science of Food and Agriculture, 80: 985-1012.

Rechinger, K. H. 1964. Flora Iranica, Akodemische Druck-U. Verlagsanstalt Graz-Austria.

Robles, C., Greff, S., Pasqualini, V., Garzino, S., Bousquet-Melou, A., Fernandez, C., Korboulewsky, N. \& Bonin, G. (2003). Phenols and flavonoids in Aleppo pine needles as bioindicators of air pollution, J. Environ. Qual., 32: 2265-2271.

Rzadkowska-Bodalska, H. (1969). Pharm. Pharmacol, 21:169.

Sagareishvili, T. G. \& Ananiya, M. D. (1990). Izv. Akad. Nauk Gruz. SSR, Ser. Khim.. 16: 155156; CA 113: 188036v.

Sahai, R., Dube, M. P. and Rastogi, R. P. 1981. Chemical and pharmacological study of Euphorbia maddeni, Indian J. Pharm. Sci., 43, 216.

Saleh A. M, Nozzolillo C. \& Altosaar, I. (1988). Flavonoid variations in Avena species, Biochem. Sys. Ecol., 16: 597-599.

Shi XH 'Liu YQ \& Kong LY. (2006). Studies on the flavones in of Chrozophora sabulosa. Zhongguo Zhong Yao Za Zhi., 31 (5): 395- 397.

Shirley, B.W. (1996) Flavonoid biosynthesis: "new" functions for an "old" pathway. Trends in Plant Science, 1, 377-382.

Simpson, M. G. \& Levin, G. A. (1994). Pollen ultrastructure of the biovulate Euphorbiaceae, International Journal of Plant Sciences, 155: 313-341. 
Singla, A. K. \& Pathak, K. (1990). Phytochemistry of Euphorbia species, Fitoterapia, LXI (6): 483-516.

Sotnikova, O. M. \& Litvinenko, V. I. (1968). Isomyricitrin from Euphorbia stepposa, Chemistry of Natural Compounds, 4 (1): 42-43.

Sotnikova, O. M., Chagovets, R. K. \& Litvinenko, V. I. (1968). New flavanone compounds from Euphorbia stepposa, Chemistry of Natural Compounds, 4 (2): 71-74.

Stace C (1980). Plant taxonomy and biosystematics. Edward Arnold publisher Ltd, London.

Talischi B ‘Modarresi M ‘Bamdad Moghadam S ‘Asnaashari S ‘Nazemiyeh.H ‘Rezazadeh H \& Delazar A. (2005). Antioxidant Activity of Methanol Extract of Chrozophora tinctoria and Identification of Two O-Glycoside Flavons Isolated from it. In: First Seminar of Medicinal and Natural Products Chemistry Shiraz. Iran.

Torck, M. et al (1969) Ann.Pharm. Fr. 27: 419-426; CA 72: 63577a.

Treutter, D. ( 2006) Significance of flavonoids in plant resistance: a review, Environmental Chemistry Letters, 4 (3): 147-157.

Trichopoulou, A., Vasilopoulou, E., Hollman, P., Chamalides, C., Foufa, E., Kaloudis, T., Kromhout, D., Miskaki, P., Petrochilou, I., Poulima, E., Stafilakis, K., \& D. Theophilou. (2000). Nutritional composition and flavonoid content of edible wild greens and green pies: a potential rich source of antioxidant nutrients in the Mediterranean diet. Food Chemistry, 70, 319-323.

Ulubelen, A., Öksuz, S., Halfon, B., Aynehchi, Y. \& Mabry, T. J. (1983). Flavonoids From Euphorbia larica, E. virgata, E. chamaesyce and E. magalanta, Journal of Natural Products, 49: 598.

Van Hoof, L., Vanden, Berqhe, D. A., Hatifield, G. M. \& Vlietinck, A. J. (1984). Plant antiviral agents, 3-methoxyflavones as potent inhibitors of viral-induced block of cell synthesis, Planta Med., 50: 513-517.

Vassallo A ،Cioffi G ‘De Simone F ‘Braca A ‘Sanogo R ،Vanella A ‘Russo A \& De Tommasi N. (2006). New flavonoid glycosides from Chrozophora senegalensis and their antioxidant activity. Nat product commun, 1 (12): 1089- 1095.

Volobueva, M. A. (1970). Phytochemical study of Euphorbia helioscopia, Trudy Alma Atinskogo Meditsinsko Instituta, 26: 451 -455, Chemical Abstracts, 77, 7254 (1972).

Williams, C. A., Harborne, J. B. and Goldblatt, P. 1986. Correlation between phenolic patterns and tribal classification in the family Iridaceae, Phytochemistry, 25: 2135-2154.

Woelfle, U., Simon-Haarhaus, B., Merfort, I \& Schempp, C. M. 2009. Reseda luteola L. extract displays antiproliferative and pro-apoptptic activities tht are related to its major flavonoids, Phytotherapy Research, 10.1002/ptr.3069.

Wong, E. 1976. Biosynthesis of flavonoids. In: Goodwin TW (ed). Chemistry and biochemistry of plant pigments, Academic Press, NY, London, 1: 464-526.

Yang. G., Zhang, L. \& Chen, G. (2010). Determination of four phenolic compounds in Scirpus yagars Ohwi by CE with amperometric detection, Chromatographia, 71 (1-2): 143-147.

Yilmaz, Y. \& Toledo, R. T. 2004. Health aspects of functional grape seed constituents, Trends Food Sci. Technol., 15422-15433.

Yuldashev, M. P., Batirov, E. K., Malikov, V. M. \& Yuldashev, N. P. (1996). Khim. Prir. Soedia, 6: 949. 


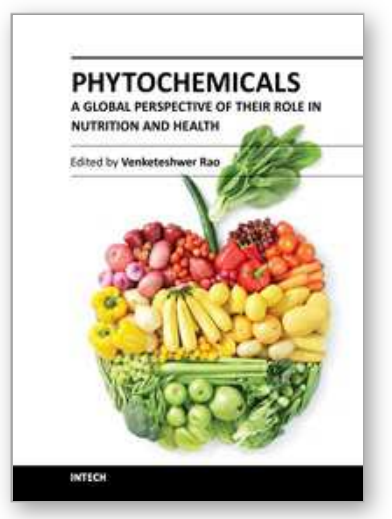

\author{
Phytochemicals - A Global Perspective of Their Role in Nutrition \\ and Health \\ Edited by Dr Venketeshwer Rao
}

ISBN 978-953-51-0296-0

Hard cover, 538 pages

Publisher InTech

Published online 21, March, 2012

Published in print edition March, 2012

Phytochemicals are biologically active compounds present in plants used for food and medicine. A great deal of interest has been generated recently in the isolation, characterization and biological activity of these phytochemicals. This book is in response to the need for more current and global scope of phytochemicals. It contains chapters written by internationally recognized authors. The topics covered in the book range from their occurrence, chemical and physical characteristics, analytical procedures, biological activity, safety and industrial applications. The book has been planned to meet the needs of the researchers, health professionals, government regulatory agencies and industries. This book will serve as a standard reference book in this important and fast growing area of phytochemicals, human nutrition and health.

\title{
How to reference
}

In order to correctly reference this scholarly work, feel free to copy and paste the following:

Mitra Noori (2012). Flavonoids in some Iranian Angiosperms, Phytochemicals - A Global Perspective of Their Role in Nutrition and Health, Dr Venketeshwer Rao (Ed.), ISBN: 978-953-51-0296-0, InTech, Available from: http://www.intechopen.com/books/phytochemicals-a-global-perspective-of-their-role-in-nutrition-andhealth/flavonoids-in-some-iranian-angiosperms

\section{INTECH}

open science | open minds

\section{InTech Europe}

University Campus STeP Ri

Slavka Krautzeka 83/A

51000 Rijeka, Croatia

Phone: +385 (51) 770447

Fax: +385 (51) 686166

www.intechopen.com

\section{InTech China}

Unit 405, Office Block, Hotel Equatorial Shanghai

No.65, Yan An Road (West), Shanghai, 200040, China

中国上海市延安西路65号上海国际贵都大饭店办公楼 405 单元

Phone: +86-21-62489820

Fax: +86-21-62489821 
(C) 2012 The Author(s). Licensee IntechOpen. This is an open access article distributed under the terms of the Creative Commons Attribution 3.0 License, which permits unrestricted use, distribution, and reproduction in any medium, provided the original work is properly cited. 